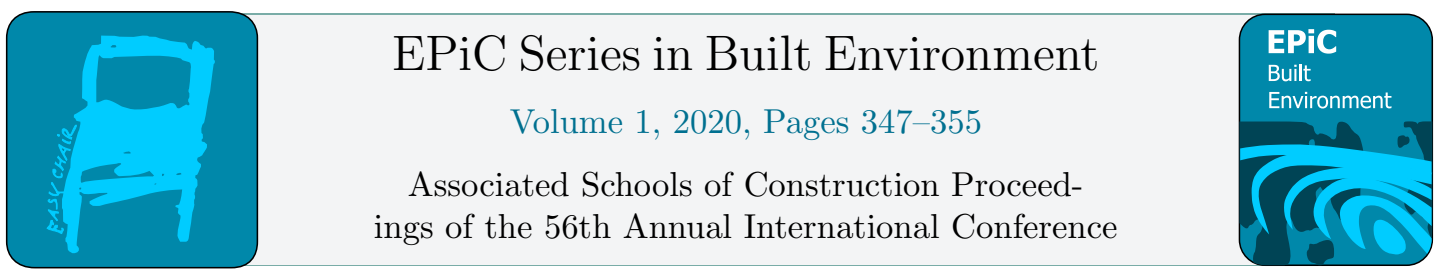

\title{
An Investigation into the Significant Causes of Disputes in the Sri Lankan Construction Industry
}

\author{
W.M. Vajira R. Edirisinghe ${ }^{1 *}$, Dianne Marsh ${ }^{2}$ \\ Fiona Borthwick ${ }^{2}$ and Alison Cotgrave ${ }^{2}$ \\ ${ }^{1}$ Sri Lanka Institute of Information Technology, Sri Lanka. \\ ${ }^{2}$ Liverpool John Moores University, UK \\ vajira.e@ sliit.lk
}

\begin{abstract}
Disputes in construction projects affect not only delay in construction progress but also its cost and potentially its quality. The construction industry of Sri Lanka contributes significantly to its economy and the cost of construction disputes can influence its economic welfare. It is important to understand the significant disputes in the Sri Lankan construction industry in order to mitigate this cost. A qualitative descriptive study has been conducted through semi-structured questionnaires analyzed using a thematic approach. The sample comprised of 10-construction industry professionals all involved in the dispute resolution process. The literature identified 7 main dispute causes as being owner related, contractor related, project related, design related, contract related, human behavior related and consultant related. The interviews identified sub themes from each, which were then ranked in order to identify those that were most significant. It was found that many of the sub themes were inter related and that one cause could be the creation of another. The lack of appropriate communication between parties and lack of team spirit were identified as the genesis of disputes in the Sri Lankan construction industry. The next stage of this research is to identify the dispute resolution methods specific to Sri Lanka in order to develop a framework for cost optimization of dispute resolution methods that link specifically with the causes of dispute as identified in this study.
\end{abstract}

\section{Introduction}

This paper is part of a current research project to investigate construction disputes in order to develop a framework for cost optimization of alternative dispute resolution (ADR) in the Sri Lankan construction industry. Construction disputes are frequent; they are a reality on every construction project and could happen at any point in time during the design or construction phase of the project (Hall, 2002). Construction disputes vary in nature, size and complexity and can be costly in terms of time and money (Ume et al., 2014). 
The construction industry plays a key role in any country's economy (Mashwama et al., 2017) and is one of the major sources of employment (Lewis, 2004). This industry is complex, its environment is challenging, and often gives rise to conflict which can impact the successful completion of the construction project (Cakmak and Cakmak, 2014). Construction conflicts affect the interests of many stakeholders, are expensive, can reduce profits and if unresolved can lead to disputes (Awakul \& Ogunlana, 2002). Disputes require resolution, which is often costly (Sambasivan et al., 2017).

Identification of causes of disputes in the construction industry can therefore help to minimize or avoid construction conflicts (De Alwis et al., 2016). The Sri Lankan construction industry is subject to numerous disputes the costs of which is impacting the successful outcome of a project in terms of time and cost. The method selected to resolve the dispute often not being the most appropriate method in terms of cost and outcome.

This paper examines the causes of disputes in the Sri Lankan construction industry in order that it can inform future research in relation to the selection of the most appropriate dispute resolution method. Qualitative semi-structured interviews with experienced construction professionals supported by an extensive literature review were adopted to identify potential disputes specific to the Sri Lankan Construction industry.

\section{Literature Review}

There have been numerous studies undertaken to determine the causes of disputes in the construction industry. Initially people were considered central to the cause of disputes citing unrealistic expectations of the parties leading to misunderstandings and lack of team spirit as a major cause (Bristow and Vasilopoulos,1995).

Disputes have also been characterized in relation to communication and construction claims. Jergeas, (2001) found causes of claims to be around misunderstanding of contract intentions, the owner's desire to reduce costs and to inadequate project planning resulting in delay in activities on site. Claims often result from the lack of communication between the parties to the construction project (Wallwork, 2003).

Further research focused on the parties to a construction contract in particular "the consultant" and negative factors "other" (Acharya and Lee, 2006). Under the category of "consultant related"; errors and omission in design, excessive extra work, differing site condition, specification related, defective design, and excessive quantity variations were identified. Whilst under the "other category" conflicts in document, change order negotiation and lack of communication, accident/safety, interpretation of escalation/de-escalation, necessity of environment improvement, environmental hazards, excessive correspondence, inadequate administration of project participants, material testing technique, difference in construction technique, acceleration or suspension of work, and negligence or negative attitudes of project participants were recognized.

Other researchers classified disputes in relation to conflict: task conflicts, relationship conflicts and process conflicts (Desivilya et al., 2010; Huan and Yazdanifard, 2012). Due to the differences among the people working together, it is inevitable to avoid disagreements, which will lead to task conflicts when taking decisions (Simons and Peterson, 2000). Further task conflicts are sub-categorized to resource allocation, agreement of rates, variation procedures and policies and judgment on quality (Dreu et al., 2001). Relationship conflicts defined by Chou and Yeh, (2007) are defined as 
disagreements between people who work together because of tension, hostility and annoyance among the individuals inside the group. Others considered communication, identified unfair behavior and effects of psychological defenses as the main cause for disputes (Mitkus and Mitkus, 2014).

The main causes of disputes in construction contract is also related to financial failure of the owner, inadequate planning of the contractor, design errors, design changes and not least different interpretations of the contract provisions (Marzouk and Moamen, 2009). A view supported by Love et al. (2010) who also identified poor contract documentation, scope changes, and adverse behavioral adaptations of individuals. Furthermore, late giving of possession by the owner, extension of time, quality of work, design errors, change order negotiations, inadequate bid information, cost overrun, lack of communication, unforeseen changes, weather, market inflation, excessive extra work and delay in drawings have been identified as causes of disputes (Bhatt et al., 2015).

Depending on the nature and mode of occurrence seven categories of disputes were classified by Cakmak and Cakmak, (2014) as owner related, contractor related, design related, contract related, human behavior related, project related and external factors related with each classification being further divided into 28 dispute causes. This was further simplified by Soni et al., (2017) who identified five main causes of construction disputes: owner related, contractor related, consultant related, third party and human behavior related and design and contract related.

\section{Method}

\subsection{Sample Description}

The research approach adopted in this study is a thematic inductive approach, which involved using the literature review to extract knowledge, which then informed the semi-structured interviews. This qualitative research embraces an interpretivist approach with the sample of 10 construction industry professionals selected through purposive sampling. All the interviewees were registered Arbitrators/Adjudicators in the Sri Lankan Government construction organization and included 4 consultant Quantity Surveyors (QS), 4 consultant engineers (CE), 1 architect and 1 lawyer. Each participant had between 12 and 46 years of experience, with a mean of 33 years of experience with the Sri Lankan Construction Industry.

\subsection{Instrumentation}

Semi-structured interviews were used to gather data via a mixture of open and close ended interview questions. The interviews were held face to face and lasted approximately 45 minutes and the questions asked were based on the six of the seven categories of disputes as classified by Cakmak and Cakmak, (2014). In addition, the "consultant related" cause identified by Soni et al., (2017) was included in the questions asked. The themes of the questions were as follows:

Owner related, Contractor related, Consultant related, Design related, Contract related, Human behavior related, Project related and External Factors

The interviews were transcribed and open coded analysis performed with Nvivo to identify sub themes from the qualitative data. These sub themes were then ranked by in order of most frequently occurring using Excel. The causes of disputes are the focus of this paper and the responses obtained from the 
interviews identified the most common causes of disputes in the Sri Lankan Construction Industry. This paper presents the initial phase of four phases of data collection to be used in the development of a conceptual framework to optimize the cost of dispute resolution methods such as ADR (alternative dispute resolution) on the main causes of dispute in Sri Lanka.

\section{Results and Analysis}

Table 1- 7 summaries the responses and identifies the sub themes under the main themes and ranks them by frequency count.

\begin{tabular}{|c|c|c|c|c|c|c|c|c|c|c|c|c|}
\hline \multicolumn{13}{|c|}{$\begin{array}{l}\text { Table } 1 \\
\text { Ranking of owner related causes of disputes }\end{array}$} \\
\hline $\begin{array}{l}\text { Owner Related Examples of the } \\
\text { cause of dispute }\end{array}$ & $\overline{\tilde{o}}$ & $\begin{array}{l}1 \\
\tilde{z} \\
\tilde{U}\end{array}$ & $\stackrel{m}{\tilde{z}}$ & $\begin{array}{r}\dot{y} \\
\tilde{\theta}\end{array}$ & $\underset{\mathbb{1}}{-}$ & 펀 & 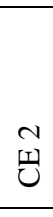 & 范 & ભ비 & $\vec{\exists}$ & 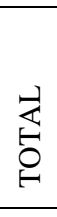 & $\begin{array}{l}\text { Ranking } \\
\text { of } \\
\text { source } \\
\text { of } \\
\text { dispute }\end{array}$ \\
\hline variations initiated by the owner & 1 & 1 & 1 & - & 1 & 1 & 1 & 1 & 1 & 1 & 9 & 1 \\
\hline payment delays & 1 & 1 & 1 & - & 1 & 1 & 1 & 1 & 1 & 1 & 9 & 1 \\
\hline change of scope & 1 & 1 & 1 & 1 & - & 1 & 1 & 1 & - & 1 & 8 & 3 \\
\hline financial failure of owner & 1 & - & - & 1 & 1 & 1 & 1 & - & 1 & 1 & 7 & 4 \\
\hline suspension of work & 1 & - & 1 & - & 1 & 1 & 1 & - & 1 & 1 & 7 & 4 \\
\hline non-payment of changes & 1 & - & - & - & - & 1 & 1 & 1 & - & 1 & 5 & 6 \\
\hline confusing requirements of owner & 1 & 1 & - & - & 1 & - & - & - & 1 & - & 4 & 7 \\
\hline owner furnished materials and Plant & 1 & - & - & 1 & 1 & - & - & - & 1 & - & 4 & 7 \\
\hline late giving of possession & 1 & 1 & - & - & 1 & - & - & - & 1 & 1 & 4 & 7 \\
\hline unrealistic expectations & 1 & & - & 1 & - & - & - & - & - & - & 2 & 10 \\
\hline
\end{tabular}

The majority of the interviewees identified "owner initiated variations" and "payment delays" as the major cause of disputes that relate specifically to the owner. The least ranked cause associated with the owner was "unrealistic expectations" as identified by two of the QS sample.

\section{Table 2}

Ranking of contractor related causes of disputes

\begin{tabular}{|c|c|c|c|c|c|c|c|c|c|c|c|c|}
\hline $\begin{array}{l}\text { Contractor Related Examples of } \\
\text { the cause of dispute }\end{array}$ & $\overline{\tilde{g}}$ & $\begin{array}{l}\tilde{O} \\
\tilde{U}\end{array}$ & $\stackrel{m}{\tilde{d}}$ & $\stackrel{\nabla}{\tilde{O}}$ & 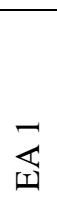 & $\vec{U}$ & 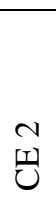 & $\overparen{U}$ & $\stackrel{\oiiint}{U}$ & $\vec{J}$ & 客 & $\begin{array}{l}\text { Ranking } \\
\text { of } \\
\text { source } \\
\text { of } \\
\text { dispute }\end{array}$ \\
\hline delays in work progress & 1 & 1 & 1 & 1 & 1 & 1 & 1 & 1 & - & 1 & 9 & 1 \\
\hline sub-contractor inefficiency & 1 & 1 & 1 & 1 & 1 & 1 & 1 & 1 & 1 & - & 9 & 1 \\
\hline inadequate planning & 1 & 1 & 1 & 1 & 1 & 1 & 1 & 1 & - & 1 & 9 & 1 \\
\hline
\end{tabular}


time extensions

quality of works

financial failure of the contractor

technical inadequacy of the

contractor

non-payment to subcontractor

under quoting

major defects in maintenance

inappropriate Claims

\begin{tabular}{llllllllllll}
1 & 1 & - & 1 & - & 1 & 1 & 1 & 1 & 1 & 8 & 4 \\
1 & 1 & 1 & - & 1 & 1 & 1 & 1 & - & 1 & 8 & 4 \\
1 & 1 & - & - & 1 & 1 & 1 & - & 1 & 1 & 7 & 6 \\
1 & 1 & - & - & 1 & 1 & 1 & - & 1 & 1 & 7 & 6 \\
1 & 1 & 1 & - & 1 & 1 & 1 & 1 & - & - & 7 & 6 \\
1 & - & - & 1 & - & 1 & 1 & - & 1 & 1 & 6 & 9 \\
1 & - & - & - & 1 & 1 & 1 & - & - & 1 & 5 & 10 \\
1 & 1 & - & - & 1 & - & - & - & - & - & 3 & 11 \\
\hline
\end{tabular}

Table 2 identifies "Inappropriate claims" as the least ranked dispute cause under contractor related, and the highest rank dispute cause is "Delay in work progress" which nine participants had acknowledged. Several participants mentioned though the "delay in work progress" is the cause that this is often interrelated with other owner related causes, such as "late giving of possession, payment delays, variations" which all delay the project.

\section{Table 3}

Ranking of Design related causes of disputes

\begin{tabular}{|c|c|c|c|c|c|c|c|c|c|c|c|c|}
\hline $\begin{array}{l}\text { Design Related Examples of the } \\
\text { cause of dispute }\end{array}$ & $\overline{\tilde{g}}$ & $\begin{array}{l}N \\
\tilde{y} \\
0\end{array}$ & $\begin{array}{l}m \\
\tilde{O} \\
0\end{array}$ & $\begin{array}{l}+ \\
\tilde{O} \\
0\end{array}$ & 芯 & $\overrightarrow{\mathrm{U}}$ & 壳 & $\bar{U}$ & II & $\bar{\theta}$ & 岕 & $\begin{array}{l}\text { Ranking } \\
\text { of source } \\
\text { of } \\
\text { dispute }\end{array}$ \\
\hline Design errors & 1 & 1 & 1 & - & 1 & 1 & 1 & 1 & 1 & 1 & 9 & 1 \\
\hline quality of design & 1 & 1 & 1 & 1 & 1 & 1 & 1 & - & 1 & - & 8 & 2 \\
\hline $\begin{array}{l}\text { availability of information } \\
\text { inadequate/incomplete }\end{array}$ & 1 & 1 & & 1 & 1 & 1 & 1 & - & 1 & 1 & 8 & 2 \\
\hline specifications & 1 & 1 & 1 & 1 & 1 & - & - & 1 & - & 1 & 7 & 4 \\
\hline Design changes & 1 & 1 & 1 & - & - & - & - & - & - & 1 & 4 & 5 \\
\hline
\end{tabular}

Table 3, "Design errors" ranked the highest with "Design changes" ranked last. Once again, several of the interviewees explained the relationship between these changes in design (design related cause) and variation resulting in a variation, which in turn could affect time.

Table 4

Ranking of Contract related causes of disputes

\begin{tabular}{|c|c|c|c|c|c|c|c|c|c|c|c|c|}
\hline $\begin{array}{l}\text { Contract Related Examples of the } \\
\text { cause of dispute }\end{array}$ & $\overrightarrow{\tilde{z}}$ & $\begin{array}{l}\sim \\
\tilde{\theta}\end{array}$ & $\stackrel{n}{2}$ & $\begin{array}{l}\dot{+} \\
\tilde{O}\end{array}$ &  & $\overrightarrow{\underline{U}}$ & I & $\bar{U}$ & 己َ̂ & $\overrightarrow{0}$ & 㝕 & $\begin{array}{l}\text { Ranking } \\
\text { of source } \\
\text { of } \\
\text { dispute }\end{array}$ \\
\hline ambiguities in contract documents & 1 & 1 & 1 & 1 & - & 1 & 1 & 1 & 1 & 1 & 9 & 1 \\
\hline risk allocation & 1 & 1 & 1 & 1 & 1 & 1 & 1 & 1 & 1 & - & 9 & 1 \\
\hline change order negotiations & 1 & - & 1 & - & 1 & 1 & 1 & - & 1 & 1 & 7 & 3 \\
\hline cost overrun & 1 & - & 1 & - & 1 & 1 & 1 & 1 & 1 & - & 7 & 3 \\
\hline
\end{tabular}


different interpretations of the contract provisions

multiple prime contracting parties

form of contract

inadequate bid information interpretation of escalation/deescalation

scope of the contract

\begin{tabular}{llllllllllll}
1 & - & 1 & - & 1 & - & - & - & 1 & 1 & 5 & 5 \\
1 & - & - & 1 & 1 & - & - & - & 1 & 1 & 5 & 5 \\
1 & - & - & 1 & - & - & - & - & 1 & 1 & 4 & 7 \\
1 & - & - & 1 & 1 & - & - & - & 1 & - & 4 & 7 \\
1 & - & - & 1 & - & - & - & - & - & 1 & 3 & 9 \\
1 & - & 1 & - & 1 & - & - & - & - & - & 3 & 9 \\
\hline
\end{tabular}

Nine interviewees out of the ten ranked "ambiguities in the contract documents" as the highest dispute cause under contract related. The QS professionals further mentioned that different interpretations of the specification and drawings brought about ambiguity. The EA1 rejected this as a disputed cause as he believed that the contract documents are the responsibility of the professionals to be unambiguous. Furthermore, EA1 cautioned that any ambiguity in these documents should have been resolved during the pre-bid meeting before signing the agreement. The least ranked dispute under the contract is "scope of the work" which interestingly was not considered an issue by the designers.

\section{Table 5}

Ranking of Human Behavioural related causes of disputes

\begin{tabular}{|c|c|c|c|c|c|c|c|c|c|c|c|c|}
\hline $\begin{array}{l}\text { Human Behavioural Related } \\
\text { Examples of the cause of dispute }\end{array}$ & $\overline{\tilde{\theta}}$ & $\tilde{O}$ & $\tilde{\mathscr{O}}$ & $\begin{array}{l}\dot{\forall} \\
\tilde{O}\end{array}$ & 茫 & $\overrightarrow{\mathrm{U}}$ & Uี & $\bar{U}$ & Uి & $\bar{\theta}$ &  & $\begin{array}{c}\text { Ranking } \\
\text { of } \\
\text { source } \\
\text { of } \\
\text { dispute } \\
\end{array}$ \\
\hline lack of document communication & 1 & 1 & 1 & 1 & 1 & 1 & 1 & 1 & 1 & 1 & 10 & 1 \\
\hline lack of team spirit & 1 & 1 & 1 & 1 & 1 & 1 & 1 & 1 & 1 & 1 & 10 & 1 \\
\hline $\begin{array}{l}\text { Unfair behaviour } \\
\text { Effects of psychological }\end{array}$ & 1 & - & 1 & 1 & - & - & - & 1 & 1 & 1 & 6 & 3 \\
\hline $\begin{array}{l}\text { differences } \\
\text { Misunderstandings among }\end{array}$ & 1 & 1 & 1 & - & 1 & - & - & - & 1 & 1 & 6 & 3 \\
\hline participants & 1 & & 1 & - & - & 1 & 1 & - & 1 & 1 & 6 & 3 \\
\hline adversarial/controversial culture & 1 & & 1 & - & 1 & - & - & - & - & 1 & 4 & 6 \\
\hline
\end{tabular}

All ten interviewees agreed upon the two highest causes of human behavior dispute as "Lack of document communication" and "Lack of team spirit". CQS1 also identified that keeping document evidence is more important in terms of the contract as it will be a resistance to disputes. CL1 expressed concern that the parties to the contract pay little interest to preparing proper documentation. All the interviewees recognized however that they should work as a team but that they have differing objectives albeit they should all be aiming towards the successful completion of the project.

Table 6

Ranking of Project related causes of disputes

\begin{tabular}{|c|c|c|c|c|c|c|c|c|c|c|c|c|}
\hline $\begin{array}{l}\text { PROJECT RELATED Examples } \\
\text { of the cause of dispute }\end{array}$ & $\overline{0}$ & $\tilde{\tilde{\theta}}$ & $\tilde{\tilde{O}}$ & $\stackrel{+}{\tilde{z}}$ & 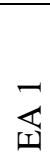 & 剀 & $\begin{array}{l}\text { ป̂ } \\
\text { ป̂. }\end{array}$ & క & 凹ึ & $\overline{\mathrm{U}}$ & 它 & $\begin{array}{c}\text { Ranking } \\
\text { of source } \\
\text { of } \\
\text { dispute }\end{array}$ \\
\hline
\end{tabular}




\begin{tabular}{lllllllllllll}
\hline unforeseen changes & 1 & 1 & 1 & 1 & 1 & 1 & 1 & - & 1 & 1 & 9 & 1 \\
complexity & 1 & 1 & 1 & 1 & 1 & 1 & 1 & - & 1 & 1 & 9 & 1 \\
site conditions & 1 & 1 & 1 & 1 & 1 & 1 & 1 & - & 1 & - & 8 & 3 \\
"Unforeseen changes" and "Complexity" of the project received the highest rank in project related \\
dispute causes (Table 6). "Site conditions "is the least ranked dispute. CL1 explained, before \\
tendering the consultant team need to prepare the designs and contract document according to the site \\
conditions and as such any cause for dispute should be identified prior to signing the contract.
\end{tabular}

\section{Table 7}

Ranking of Consultant related causes of disputes

\begin{tabular}{|c|c|c|c|c|c|c|c|c|c|c|c|c|}
\hline Consultant Related & $\overrightarrow{\tilde{O}}$ & $\begin{array}{l}\sim \\
\tilde{z}\end{array}$ & $\tilde{\tilde{\sigma}}$ & $\stackrel{+}{\tilde{O}}$ & $\underset{\mathbb{I}}{\overparen{I}}$ & $\overrightarrow{\mathrm{U}}$ & $\begin{array}{l}N \\
\text { ț }\end{array}$ & $\bar{U}$ & $\stackrel{\text { II }}{0}$ & $\vec{U}$ & 离 & $\begin{array}{c}\text { Ranking } \\
\text { of source } \\
\text { of } \\
\text { dispute }\end{array}$ \\
\hline errors and omissions in design & 1 & - & 1 & 1 & 1 & 1 & 1 & 1 & 1 & 1 & 9 & 1 \\
\hline defective design & 1 & 1 & 1 & - & 1 & 1 & 1 & 1 & 1 & - & 8 & 2 \\
\hline delay in Drawings & 1 & - & 1 & 1 & 1 & 1 & 1 & - & 1 & 1 & 8 & 2 \\
\hline specification related & 1 & - & 1 & 1 & 1 & - & - & 1 & - & 1 & 6 & 4 \\
\hline excessive quantity variations & 1 & - & - & - & 1 & 1 & 1 & - & 1 & 1 & 6 & 4 \\
\hline excessive extra work & 1 & 1 & 1 & - & 1 & - & - & - & 1 & - & 5 & 6 \\
\hline lack of experience & 1 & 1 & 1 & 1 & - & - & - & - & 1 & - & 5 & 6 \\
\hline differing site conditions & 1 & - & 1 & - & 1 & - & - & - & 1 & - & 4 & 8 \\
\hline
\end{tabular}

"Errors and omissions in design" is the highest ranked dispute cause under consultant related dispute causes in Table 7. "Different site conditions" is the least ranked dispute.

\section{Discussion}

"Variation" is ranked highest in owner related disputes and "design changes" ranked lowest in design related disputes. This difference is due to a design change being a variation in a contract. Interviewees explained that some variations are due to changes to quantities, quality, timing, material or omission of work and change in work sequence. These factors can then ultimately change the design. The key point in variation is money. When any of the variations affect the cost of the project, it can lead to a dispute. Under the consultant related theme "errors and omissions in design" was ranked highest identifying an issue which could be mitigated if the documentation on the project is completed correctly. The document communication is one of the highest ranked disputed cause identified by interviewees. The link between payment delay by the owner and delay in work progress by the contractor clearly shows that most of the dispute causes are inter related. However, to resolve those disputes document evidence is important. Another key aspect is that all parties involved work as one team and ultimately this will improve communication, which was identified by all ten interviewees as the highest ranked issue linked to human behavior despots. 


\section{Conclusion}

Identifying causes of disputes supports dispute avoidance and loss prevention in the Sri Lankan Construction industry. Lack of communication among the contracting parties was identified by many researchers including Kumaraswamy, (1997); Wallwork, (2003); Chou and Yeh, (2007); Mitkus and Mitkus, (2014); Love et al., (2010). This research identified that the major issue in relation to communication specifically relates to "lack of document communication" associated with "lack of team spirit". These causes could not be considered in isolation as it was found that many of the sub themes were inter related and that one cause could influence the creation of another. Poor communication at pre tender stage also leads to "errors and omissions in design" which in turn result in "variations" leading to disputes. It can be concluded that lack of appropriate communication between parties to a project is a major cause of dispute in the Sri Lankan construction industry and if disputes are to be mitigated that priority should be given to improving communication via better collaboration at the documentation production stage. Healthier communication is key in order to improve team spirit and transform the hostile, adversarial owner-contractor relationship into a more collaborative and productive team (Gransberg and Scheepbouwer, 2015).

\section{References}

Acharya, N. K., \& Lee, Y. D. (2006). Conflicting factors in construction projects: Korean perspective. Construction and Architectural Management

Awakul, P. and Ogunlana, S. (2002) the effect of attitudinal differences on interface conflicts in large scale construction projects: a case study. Construction Management and Economics, 20 (4), pp.365377

Bhatt, R., Shah, A. and Bhavsar, J. (2015) Ranking of "Causes of Disputes" and "Use of Dispute Resolution Methods" for Construction Industry in Gujarat. National conference on "Recent Research \& Development in Core Discipline of Engineering, Vadodara

Bristow, D.I., and Vasilopoulos, R. (1995). "ThenewCCDC2: Facilitating dispute resolution of construction projects.” Construction Law Journal, 11, 95.

Cakmak, E. and Cakmak, P. (2014) An Analysis of Causes of Disputes in the Construction Industry Using Analytical Network Process. Procedia - Social and Behavioral Sciences, 109 pp.183-187

Chou,H.W. and Yeh,Y.J.(2007), "Conflict, conflict management and Performance in ERP teams," Social Behavior and Personality, Vol. 35 No. 8, pp. 1035-1048.

De Alwis, I., Abeynayake, M. and Francis, M. (2016), Dispute avoidance model for Sri Lankan construction industry. The 5th World Construction Symposium 2016: Greening Environment, Eco Innovations \& Entrepreneurship, Colombo: Emerald Group Publishing pp.162-173

Desivilya, H.S., Somech, A. and Lidgoster, H. (2010), "Innovation and conflict management in work teams: the effects of team identification and task and relationship conflict," Negotiation and Conflict Management Research, Vol. 3 No. 1, pp. 28-48. 
Dreu, C.K.W.D., Evers, A., Beersma, B., Kluwer, E.S. and Nauta, A. (2001), “A theory-based measure of conflict management strategies in the workplace," Journal of Organizational Behavior, Vol. 22 No. 6, pp. 645-668.

Gransberg, D. and Scheepbouwer, E. (2015) U.S. Partnering Programs and International Partnering Contracts and Alliances. Transportation Research Record: Journal of the Transportation Research Board, 2504 (1), pp.73-77 DOI: 10.3141/2504-09.

Hall, J. M. (2002). Ineffective communication: Common Causes of Construction Disputes Alliance"s Advisory Council Legal Notes. Vol. 13, No.2

Huan, L.J. and Yazdanifard, R. (2012), "The difference of conflict management styles and conflict resolution in workplace," Business \& Entrepreneurship Journal, Vol. 1 No. 1, pp. 141-155.

Illankoon, I., Tam, V., Le, K. and Ranadewa, K. (2019) Causes of disputes, factors affecting dispute resolution and effective alternative dispute resolution for Sri Lankan construction industry. International Journal of Construction Management, pp.1-11 DOI: 10.1080/15623599.2019.1616415.

Jergeas, G. (2001) Claims and Disputes in the Construction Industry. AACE International Transactions, pp.CDR.03.1-4

Lewis, T. (2004). The construction industry in the economy of Trinidad \& Tobago. Construction Management and Economics, 22(5), pp.541-549.

Marzouk, M. and Moamen, M. (2009). A framework for estimating negotiation amounts in construction projects. Construction Innovation, 9(2), pp.133-148.

Mashwama, N., Aigbavboa, C. and Thwala, D. (2017) An Assessment of the Critical Success factor for The Reduction of Cost of Poor Quality in Construction Projects in Swaziland. Procedia Engineering, 196 pp.447-453

Mitkus, S. and Mitkus, T. (2014). Causes of Conflicts in a Construction Industry: A Communicational Approach. Procedia - Social and Behavioral Sciences, 110, pp.777-786.

Murali Sambasivan, T.J. Deepak, Ali Nasoor Salim, Venishri Ponniah, (2017) "Analysis of delays in Tanzanian construction industry: Transaction cost economics (TCE) and structural equation modeling (SEM) approach," Engineering, Construction and Architectural Management, Vol. 24 Issue: 2, pp. 308325

Simons, T.L. and Peterson, R.S. (2000), “Task conflict and relationship conflict in top management teams: the pivotal role of intragroup trust," Journal of Applied Psychology, Vol. 85 No. 1, pp. 102-111,

Soni, S., Pandey, M. and Agrawal, S. (2017) Conflicts and Disputes in Construction Projects: An Overview. International Journal of Engineering Research and Applications, 07 (06), pp.40-42 DOI:

Ume, M., Farooqui, R. and Azhar, S. (2014) Key Causes of Disputes in the Pakistani Construction Industry- Assessment of Trends from the Viewpoint of Contractors. Available at: http://ascpro0.ascweb.org/archives/cd/2014/paper/CPRT262002014.pdf

Wallwork, J. (2003) Communicating the Dispute. AACE International Transaction, pp.CDR.20.1-3 